\title{
PERLUNYA PENERAPAN SYSTEM IMFORMASI MANAJEMEN DISEKOLAH
}

\author{
Widiyati Noverta \\ widiyatinoverta@gmail.com
}

\begin{abstract}
Abstrak
Dalam dunia pendidikan tentunya tidak terlepas dari kemajuan ilmu pengetahuan dan perkembangan teknologi informasi. Serta dengan kemajuan tersebut menghadiran sebuat sisten yang digunakan untuk mempermudah dalam kinerja seseorang maupun suatu organisasi tidak terkecuali sekolah. Sistem informasi manajemen sangat perlu dilakukan disekolah agar pencpaian segala hal terwujud dengan efektif dan efisien.
\end{abstract}

Kata kunci : penerapan, SIM, sekolah

\section{PENDAHULUAN}

Seiring dengan berkembangnya kemajuan ilmu pengetahuan, teknologi dan informasi yang memiliki dampak posotif maupun negatif bagi kehidupan manusia menyebabkan banyaknya perubahan pada elemen masyarakat yang menguntungkan bagi setiap orang maupun bagi suatu lembaga ataupun organisasi. Tidak terkecuali pada bidang pendidikan. Dengan kemajuan teknologi dan informasi tersebut menciptakan suatu kemudahan dalam pendataaan pada dunia pendidikan yang disebut dengan sisten imfomasi manajemen. Pada system informasi dan manajemen yang melibatkan teknologi memudahkan dalam mendata, mencari dan menemukan data. Merubah sistem manual menjadi system databes. Sistem imformasi manajemen tentunya sangat perlu untuk dilaksanakan disekolah agar segala hal yang berhubungan dengan pendataan menjadi lebih efektif dan efisien. Serta lebih akurat dan tidak membutuhkan tenaga seperti system manual.

Meski banyak kendala dalam pelaksanaannya system informasi dan manajemen tetap merupakan hal yang sangan disarankan untuk dilakukan pada suatu lembaga terutama pada sekolah. Menurut (Vindi Agustiandra[1], 2019)Sabandi dengan pemanfaatan ilmu pengetahuan dan teknologi yang semakin berkembang dapat meningkatkan kualitas pembelajaran. 
PEMBAHASAN

\section{A. Pengertian Sistem Informasi Manajemen}

System informasi manajemen itu sendiri merupakan suatu metode yang memanfaatkan kecanggihan ilmu pengetahuan, teknologi dan informasi yang berupa pengumpulan data, menyimpan, mengolah dan menghasilkan sebuah informasi untuk pengambilan keputusan. Menurut George M. (2004:100) dalam (Milka, 2014) mendefinisikan sistem informasi manajemen (SIM) sebagai serangkaian subsistem informasi yang menyeluruh dan terkoordinasi secara rasional terpadu yang mampu mentransformasi data sehingga menjadi informasi lewat serangkaian cara guna meningkatkan produktifitas yag sesuai dengan gaya dan sifat manajer atas dasar kriteria mutu yang telah ditetapkan. Begitu pula juga yang dikemukakan Raymond \& George Schell (2004:259-260) bahwa sistem informasi manajemen merupakan suatu sistem berbasis komputer yang menyediakan informasi bagi beberapa pemakai dengan kebutuhan serupa. Kemudian Raymond (1995:5) menegaskan bahwa secara sederhana sistem informasi manajemen merupakan seluruh aktivitas memperoleh informasi, menggunakannya seefektif mungkin dan membuangnya pada saat yang tepat.

Untuk melaksanakan metode system informasi dan manajemen dilakukan dengan beberapa langkah diantaranya ialah : 1). Proses penerimaan data sebagai masukan yang disebut dengan input data, 2) memproses data dengan melakukan beberapa hal seperti perhitungan, penggabungan, hingga pemutakhiran perkiraan dan lain-lain, 3). Keluaran atau ouput sebagai informasi yang diperoleh.

\section{B. Tujuan dan manfaat Sistem Informasi Manajemen}

Tujuan umum sekolah menggunakan system imformasi manajemen tidak lain ialah untuk mempermudah kinerja sekolah juga untuk mengikuti perkembangan zaman agar tidak tertinggal dari segi teknologi dan informasi. Tujuan khusus dari sistem informasi manajemen antara lain :

- Sistem informasi maanjemen menyediakan informasi yang akurat dan jelas untuk pengambilan keputusan.

- Sistem informasi manajemen menyediakan informasi untuk melakukan perencanaan, proses, 
pengendalian, evaluasi serta untuk melakukan perbaikan berkelanjutan.

- Menyediakan informasi apasaja yang dibutuhkan baik oleh kepala sekoah, guru maupun teaga kependidikan lainnya.

Adapun beberapa manfaat system informasi manajemen antara lain :

1. Menjamin tersedianya kualitas dan keterampilan dalam memanfaatkan sistem informasi secara kritis.

2. Meningkatkan aksesbilitas data yang ada secara akurat dan tepat waktu bagi para pemakai, tanpa mengharuskan adanya perantara sistem informasi.

3. Mengidentifikasi kebutuhankebutuhan akan keterampilan pendukung sistem informasi.

4. Mengembangkan proses perencanaan yang efektif.

\section{Implementasi Sistem Informasi Manajemen di Sekolah}

Pengelolaan menggunakan sistem informasi manajemen disekolah sangatlah perlu dilakukan mengingat banyaknya data yang harus diinput, proses dan menjadi keluaran atau output yang menghasilkan informasi yang akan menjadi suatu pertimbangan dalam pengambilan keputusan baik oleh kepala sekolah maupun guru. Juga berhubungan dengan perencanaan pembelajaran, pelaksanaaan pembelajaran, pengawasan hingga evaluasi pembelajaran.

\section{KESIMPULAN}

Dapat disimpulkan bahwa sistem informasi dan manajemen perlu dilaksanakan pada suatu organisasi terutama sekolah. Karna dengan penggunakaan sistem informasi manajemen menjadikan kinerja lebih mudah, efektif dan efisien. Serta dengan memanfaatkan teknologi informasi yang canggih tersebut dapat meningkatkan dan menunjang segala bentuk pembelajaran dan prestasi siswa disekolah.

\section{SARAN}

Untuk sekolah yang telah menggunakan sistem informasi manajemen perlu dipertahan kan dan melakukan lebih banyak hal lagi dengan penggunaannya, dan untuk sekolah yang belum menggunakan sistem informasi manajemen upayakan untuk menggunakannya agar sekolah juga tidak tertinggal dari sekolah-sekolah lainnya dan demi kemajuan pendidikan di Indonesia. 


\section{DAFTAR PUSTAKA}

Milka. (2014). Pemanfaatan Sistem

Informasi Manajemen Di Sekolah

Menengah Kejuruan. Keguruan Dan

Ilmu Pendidikan, III, 1-13. Retrieved

from file:///D:/SEMESTER 5/SIM/190-

Article Text-638-1-10-20171227.pdf
Vindi Agustiandra[1], A. S. (2019). Persepsi

Guru Terhadap Penerapan Sistem

Informasi Manajemen Akademik Di

Sekolah Menengah Kejuruan (Smk)

Negeri 3 Padang. Bahana Manajemen

Pendidikan, 8, 1-8. Retrieved from

file:///D:/SEMESTER 5/SIM/103704-

29550-1-PB sim pak AS.pdf 